\title{
KORZYŚCI ORAZ PROBLEMY ZWIĄZANE Z WYKORZYSTANIEM E-LEARNINGU W NAUCZANIU JĘZYKÓW OBCYCH
}

\author{
KRZYSZTOF BAEABAN \\ Uniwersytet Wroctawski \\ krzysztof.balaban@uwr.edu.pl \\ ORCID: 0000-0002-7692-0415
}

\section{STRESZCZENIE}

E-learning stanowi nowoczesną metodę kształcenia, która coraz częściej jest stosowana w edukacji. Z uwagi na fakt, iż forma ta pozwala na naukę $w$ dowolnym czasie i miejscu jest chętnie wykorzystywana przez uczniów. W artykule omówiono korzyści oraz problemy związane z wykorzystaniem e-learningu w nauczaniu języków obcych.

SŁOWA KLUCZOWE: nauczanie, e-learning, języki obce.

\section{BENEFITS AND PROBLEMS RELATED TO THE USE OF E-LEARNING IN FOREIGN LANGUAGE TEACHING}

\section{ABSTRACT}

E-learning is a modern method of education, which is increasingly used in education. This method allows students to learn at any time and place. The article discusses the benefits and problems associated with the use of e-learning in foreign language teaching.

KEYWORDS: teaching, e-learning, foreign languages.

\section{WPROWADZENIE}

Celem niniejszego artykułu jest przedstawienie korzyści oraz problemów związanych z wykorzystaniem e-learningu w nauczaniu języków obcych.

Pojęcie e-learning jest definiowane na wiele sposobów. Najczęściej jest określane jako proces przekazywania informacji i wiedzy za pomocą mediów elektronicznych przez sieci komputerowe albo jako naukę z wykorzystaniem nośników elektronicznych. E-learning jako nowoczesna oraz interaktywna metoda kształcenia jest coraz częściej stosowana w edukacji. $Z$ uwagi na fakt, że ta forma nauczania pozwala na naukę $\mathrm{w}$ dowolnym czasie i miejscu jest chętnie wykorzystywana w nauczaniu języków obcych.

Tę formę nauki dość często nazywa się "nauczaniem na odległość”, w którym stroną przekazującą wiedzę i egzaminującą jest komputer wraz ze stosownym oprogramowaniem i w którym brak jest fizycznego kontaktu $\mathrm{z}$ nauczycielem. Polski naukowiec, członek Rady ds. Informatyzacji Edukacji, profesor Maciej M. Sysło słusznie zauważa, że nie należy utożsamiać tych dwóch 
pojęć, gdyż ich zakres znaczeniowy nie jest taki sam - nauczanie na odległość nie musi przyjmować form jedynie elektronicznych (Sysło 2005: 58-59).

Warto zaznaczyć, że wykorzystanie e-learningu w nauczaniu oferuje liczne korzyści, z których najczęściej wymieniana jest możliwość wyboru tempa, czasu oraz miejsca nauki. Istnieje jednak wiele wad e-learningu, takich jak m.in. brak osobistego kontaktu z nauczycielem, czy wrażenie odosobnienia, którego doświadczają uczniowie uczący się na odległość.

\section{WPŁYW ROZWOJU INTERNETU NA POPULARNOŚĆ KURSÓW E-LEARNINGOWYCH}

Internet jest jednym z najdynamiczniej rozwijających się medium na świecie. Zakres usług i informacji oferowanych przez Internet jest bardzo szeroki. W ostatnich latach korzystanie $\mathrm{z}$ tego medium stało się elementem codziennego funkcjonowania niemal każdego człowieka. Popularność i powszechność Internetu potwierdzają liczne badania. Przykładowo, wyniki badań przeprowadzonych przez Centrum Badania Opinii Społecznej (CBOS) pokazuja, że systematycznie zwiększa się $\mathrm{w}$ Polsce odsetek osób korzystających $\mathrm{z}$ Internetu. Opublikowany $\mathrm{w}$ lipcu 2019 roku komunikat z tych badań przedstawia, że regularni użytkownicy Internetu to obecnie $w$ Polsce blisko siedmiu na dziesięciu dorosłych. Najwięcej użytkowników jest wśród młodszych pokoleń Polaków, a nieobecność w sieci związana jest przede wszystkim ze starszym wiekiem. Wiek nie tylko decyduje w znacznym stopniu o byciu online, ale też określa styl korzystania z Internetu. Młodsi użytkownicy spędzają w sieci najwięcej czasu, a znaczny ich odsetek jest dostępny online praktycznie cały czas. W wielu przypadkach są oni także bardziej aktywni od starszych internautów w wykorzystywaniu dostępnych $\mathrm{w}$ sieci usług i funkcji. Warto $\mathrm{w}$ tym miejscu dodać, że inne badania przeprowadzone przez Gemius/PBI (Polskie Badania Internetu) opublikowane $\mathrm{w}$ październiku 2019 roku pokazuja, że wzrasta zainteresowanie internautów stronami związanymi z edukacją.

Powszechny dostęp do Internetu daje większą możliwość wglądu do wiedzy i informacji. Pozwala to na przełamanie bariery związanej z miejscem i czasem $\mathrm{w}$ procesie nauczania. Jednym z przejawów takiego zjawiska jest coraz szersza oferta instytucji świadczących usługi w postaci kursów e-learningowych. Jest to związane z uelastycznieniem oferty dydaktycznej i dostosowywaniem się do potrzeb rynku.

\section{WYKORZYSTANIE KURSÓW E-LEARNINGOWYCH W NAUCZANIU}

Kursy e-learningowe mogą obejmować wszystkie poziomy nauczania od szkoły podstawowej po uczelnię wyższą. Wspierają edukację pracowników firm, mogą pomagać w krzewieniu oświaty i kultury. 
Szkolenia oraz kursy na odległość cieszą się dużym zainteresowaniem. Prowadzone są zarówno w środowiskach akademickich, jak i biznesowych. Wiele uczelni korzysta $\mathrm{z}$ takich form nauczania. Stanowią one uzupełnienie albo wsparcie tradycyjnego modelu kształcenia. Niektóre szkoły języków obcych prowadzą zajęcia w mieszanej formule, tzw. blended learning, która łączy tradycyjne metody nauki z aktywnościami prowadzonymi zdalnie za pomocą komputera.

Czynnikami przemawiającymi za wprowadzaniem nauczania w postaci elearning w różnych ośrodkach edukacyjnych są:

- poszerzanie oferty o nowy typ szkoleń w postaci e-learningu;

- prowadzenie kursów nawet w przypadku braku wystarczającej liczby sal, czy w sytuacji, gdy lektor prowadzący zajęcia jest osobą mieszkającą w odległej miejscowości;

- oferowanie nauki języków obcych osobom, które nie są w stanie wygospodarować czasu na udział w zajęciach w określonych godzinach i terminach.

Nauczyciele języków obcych poprzez techniki zdalnego nauczania mogą doskonalić się w następujących obszarach:

- samokształcenie - za pośrednictwem edukacyjnych stron internetowych;

- wymiana doświadczeń on-line z innymi nauczycielami;

- szkolenia, organizowane przez instytucje edukacyjne, które prowadzone są m.in. za pomocą platform e-learningowych, np. Moodle;

- zdobywanie materiałów dydaktycznych oraz zarządzanie procesem szkoleniowym.

\section{ZALETY E-LEARNINGU}

Ośrodki edukacyjne znając zalety e-learningu, widzą duży potencjał dla swojego rozwoju w wykorzystaniu takiej metody kształcenia. Bardzo ważną korzyścią w tym aspekcie jest swoboda w wyborze tempa, czasu oraz miejsca nauki. W trakcie tradycyjnego kształcenia tempo nauki jest zazwyczaj narzucane przez innych uczniów lub nauczyciela. E-learning daje możliwość dopasowania tempa nauki do indywidualnych możliwości uczniów. Naukę można podzielić na kilka etapów w taki sposób, aby w ciągu dnia nie przeszkadzało to w innych obowiązkach.

E-learning pozwala również na wybór miejsca, w jakim osoba zainteresowana chce się uczyć. Może to robić tam, gdzie jej to najbardziej odpowiada - w szkole, w domu czy w pracy.

Ważną zaletą jest także możliwość wyboru czasu, jaki przeznaczany jest na naukę. Uczeń ma dużo swobody w tym zakresie, ale musi w związku z tym 
posiadać dobrą organizację i samodyscyplinę. $Z$ tego względu stanowi to dużo lepsze rozwiązanie, niż w przypadku tradycyjnego nauczania, gdzie jest narzucony sztywny plan zajęć lekcyjnych, do którego trzeba się dostosować (por. Clarke 2004: 15).

Ta forma nauczania spotyka się z entuzjastycznym przyjęciem ze strony studentów, ponieważ umożliwia bardziej elastyczny dostęp do edukacji osobom, które mają trudności z podjęciem nauki języków obcych w tradycyjnej postaci.

To z kolei stanowi szansę dla szkół języków obcych, które dostrzegają w tej formie możliwość pozyskania większej liczby uczniów. Warto podkreślić, że lektorzy, szczególnie młodzi, są zainteresowani podnoszeniem swoich kwalifikacji zawodowych poprzez zdobywanie wiedzy i praktycznych umiejętności $\mathrm{w}$ zakresie wykorzystywania nowych technologii $\mathrm{w}$ nauczaniu języka obcego.

Liczne ośrodki edukacyjne podejmują działania zmierzające do uproszczenia i usprawnienia procesu dydaktycznego poprzez wykorzystywanie e-learningu. Stosowane systemy i technologie informacyjne ułatwiają komunikację pomiędzy nauczycielem a uczniem. Narzędzia te spełniają swoją rolę kiedy są intuicyjne i proste $\mathrm{w}$ obsłudze. Łatwość ich wykorzystywania powinna dotyczyć zarówno przygotowywania materiałów, jak również korzystania z nich przez kursantów.

Ważną zaletą wprowadzenia e-learningu jest redukcja kosztów realizacji kursów i oszczędność czasu, która wynika $\mathrm{z}$ eliminacji czynności przygotowawczych. Istotny jest także fakt, iż e-learning daje możliwość łatwej i szybkiej modyfikacji, rozbudowy oraz aktualizacji treści szkoleniowych. Szkolenia przeprowadzane w takiej formie wyróżniają się dużą efektywnością, wynikającą z odpowiedniej konstrukcji materiału dydaktycznego.

Administrowanie kursami i możliwość monitorowania postępów uczniów oraz procesu nauczania w tej metodzie jest dużo łatwiejsze, niż w tradycyjnym kształceniu. Dzięki temu w przypadku e-learningu materiały szkoleniowe i informacje są zarządzane wydajniej i sprawniej.

E-learning daje także możliwość monitorowania w czasie rzeczywistym wyników nauczania. Oznacza to otrzymywanie pełnego oraz przejrzystego obrazu wiedzy, kompetencji i umiejętności osoby, która przeszła kurs. Z kolei proces sprawdzania egzaminów oraz generowania $\mathrm{z}$ nich raportów jest zautomatyzowany, co skutkuje przyspieszeniem tego procesu i daje oszczędność czasu (Plebańska, Kula 2010: 12).

Najważniejsze zalety e-learningu:

- przekaz za pomocą nośników multimedialnych odpowiada potrzebom i oczekiwaniom odbiorców;

- szybkość przekazywania informacji, wiedzy i umiejętności;

- dowolny czas nauki; 
- indywidualny proces nauczania;

- brak stałego miejsca odbywania się zajęć, co bezpośrednio wpływa na zmniejszenie kosztów wynajmu pomieszczenia i sprzętu dydaktycznego.

\section{WADY E-LEARNINGU}

Do głównych wad e-learningu należy zaliczyć wysokie koszty szkolenia i konieczność zaangażowania dużych zasobów oraz posiadania odpowiedniej infrastruktury informatycznej. Wątpliwość może budzić wiarygodność prowadzonych egzaminów, które sprawdzają umiejętności i wiedzę kursantów. Nie można mieć całkowitej pewności, że egzamin został rozwiązany samodzielnie przez ucznia lub bez korzystania z pomocy.

Problemem $\mathrm{w}$ takich formach nauczania mogą być także bariery mentalne jego uczestników, takie jak negatywne nastawienie do e-learningu, czy niechęć wobec pracy z komputerem. Brak kompetencji informatycznych może być przeszkodą w stosowaniu e-learningu. Kiedy uczeń nie potrafi obsługiwać komputera na poziomie, jaki jest niezbędny do realizacji kursu, jego przeprowadzenie nie jest możliwe. Trudnością jest również brak odpowiedniej motywacji wewnętrznej i samodyscypliny osób, które uczestniczą w kursie oraz mniejsze możliwości interakcji z innymi uczestnikami takiego nauczania (por. Plebańska, Kula 2010: 12).

Przygotowanie cyklu lekcji z wykorzystaniem e-learningu jest przedsięwzięciem kosztownym i złożonym. Jego realizacja, prowadzona przez nauczyciela języków obcych, powinna odbywać się przy wsparciu wyspecjalizowanych fachowców, takich jak: graficy komputerowi, animatorzy i programiści. Scenariusz lekcji jest kluczowy dla jakości kształcenia. W przypadku tradycyjnych zajęć lektor może skorygować jakąś pomyłkę w trakcie prowadzonych zajęć. Natomiast w przypadku zajęć zaprogramowanych najczęściej nie ma takiej możliwości. $Z$ tego względu całość kursu powinna być dopracowana w taki sposób, aby maksymalnie wykluczyć jakiekolwiek pomyłki.

Duża pracochłonność procesu produkcji materiałów do e-learningu może stanowić zagrożenie dla stałego i bieżącego modyfikowania zawartości lekcji. W tym miejscu należy zwrócić uwagę na fakt, iż właśnie elastyczna modyfikacja form i treści kształcenia jest podstawą dla poprawy jakości zajęć. W nauczaniu tradycyjnym nauczyciel natychmiast otrzymuje informację zwrotną dotyczącą zrozumiałości materiałów dydaktycznych i właściwego ich doboru. W tym przypadku często stosuje się zmiany co do metod dydaktycznych. Natomiast materiały wykorzystywane do e-learningu zwykle nie dają takiej możliwości, dlatego też ich wcześniejsze prawidłowe przygotowanie jest tak istotne. W innym przypadku może okazać się, że e-learning nie wnosi nic nowego do kształcenia uczniów, a oni muszą sami wyszukiwać zrozumiałych dla nich treści $\mathrm{z}$ wybranej tematyki. 
Zagwarantowanie interaktywnego procesu zdobywania wiedzy stanowi duże wyzwanie dla e-learningu. Nieliczni uczniowie potrafią być całkowicie samodzielni i bez pomocy mentora umieją opanować nowe obszary wiedzy. W e-learningu zakłada się, że uczeń, wsparty materiałami dydaktycznymi w formie elektronicznej sam przyswoi określony materiał. Kiedy napotka trudności w zrozumieniu określonego materiału, może skontaktować się zdalnie $\mathrm{z}$ nauczycielem. Nic jednak nie zastąpi mu bezpośredniego kontaktu z lektorem.

Badanie mające na celu ocenę stanu faktycznego e-edukacji językowej w polskim szkolnictwie wyższym, przeprowadzone przez Małgorzatę Świerk (Świerk 2014) wykazało, że nauczyciele nie są zachęcani do wykorzystywania technologii informacyjnych i komunikacyjnych w nauczaniu języków obcych. W Polsce brakuje dobrego systemu motywacyjnego wynagradzania nauczycieli języków obcych oraz premiującego korzystanie z innowacyjnych metod i technik nauczania.

Świerk słusznie zauważa, że należy zadbać o współpracę między nauczycielem i kursantami oraz wymianę doświadczeń i przykładów dobrych praktyk. W tym celu autorka badania proponuje wprowadzenie następujących działań:

- mentoring;

- obserwacja koleżeńska;

- ściślejsza współpraca autorów cyfrowych materiałów dydaktycznych z metodykami zdalnego nauczania.

Wielopłaszczyznowe współdziałanie podniesie bowiem jakość kształcenia z wykorzystaniem e-learningu i pozwoli nauczycielom skoncentrować się na aspektach pedagogicznych wykorzystywania technologii informacyjnych i komunikacyjnych w procesie nauczania.

Najważniejsze wady e-learningu:

- brak bezpośredniego kontaktu ucznia z nauczycielem;

- duży koszt wdrożenia (zakup platformy, sprzętu);

- konieczność posiadania silnej motywacji i chęci uczenia się;

- problemy ze sprawdzaniem efektywności i wyników nauczania.

\section{Podsumowanie}

Przedstawione korzyści i problemy wynikające z wykorzystania e-learningu w nauczaniu języków obcych pokazują że istnieje szereg istotnych czynników, które powinny być uwzględnione przy nauczaniu, aby przynosiło ono pożądane efekty.

Reasumując - nauka języka obcego z wykorzystania e-learningu stawia wiele wymagań i może stwarzać liczne problemy. Podjęcie decyzji o wprowadzeniu nauki języka obcego z wykorzystaniem e-learningu powinno być 
dobrze przemyślane i uzasadnione. Wdrożenie tego typu kształcenia jest bardzo kosztowne. Wymaga to posiadania odpowiedniej bazy technologicznej, przeszkolenia nauczycieli oraz wsparcia uczących się. Taka forma nauczania wymaga czasu, motywacji i dużej samodyscypliny. Nauka języka obcego z zastosowaniem e-learningu, nawet $\mathrm{w}$ trybie synchronicznym, nie ma na celu zastąpienia bezpośredniego kontaktu z lektorem. Uczniowie uczestniczący $\mathrm{w}$ zajęciach powinni mieć zapewnioną możliwość bezpośredniej konwersacji $\mathrm{w}$ danym języku. Problemy, jakie mogą wystąić przy zastosowaniu tej formy nauczania powodują że wprowadzenie nauki języka obcego z zastosowaniem elearningu powinno mieć miejsce tylko wtedy, kiedy istnieją przesłanki, że takie nauczanie może być równie efektywne jak zajęcia w modelu tradycyjnym.

\section{BIBLIOGRAFIA}

ClARKE, A. (2007), E-learning: nauka na odległość, Warszawa, Wydawnictwa Komunikacji i Łączności.

FELIKSIAK, M. Raport z badań: Korzystanie z internetu [online]. Warszawa: CBOS, 2019 [Dostęp: 12/10/2019]. Materiały dostępne na stronie: <https://www.cbos .pl/SPISKOM.POL/2019/K_095_19.PDF>.

PlEBAŃSKA, M.; KULA, I. (2011), E-learning: treści, narzędzia, praktyka, Warszawa, ALMAMER Szkoła Wyższa.

WYNIKI BADANIA GEMIUS/PBI. Polski Internet we wrześniu 2019 r. [online]. Warszawa: Polske Badania Internetu, 2019 [Dostęp: 12/10/2019]. Materiały dostępne na stronie: <http://pbi.org.pl/raporty/polscy-internauci-we-wrzesniu-2019/>.

SYSŁO, M. (2005), „Rozwój technologii informacyjnej a edukacja - stan, kierunki, wyzwania", w Holistyczne i analityczne metody diagnostyki edukacyjnej. Perspektywy informatyczne egzaminów szkolnych, Niemierko, B.; Szyling, G. (red.), Gdańsk, Fundacja Rozwoju Uniwersytetu Gdańskiego, 34-60.

ŚWIERK, M. (2014), "Jakość e-edukacji językowej w polskim szkolnictwie wyższym", Języki Obce w Szkole, 1, 43-46. 